\title{
FILM BEYOND BOUNDARIES: FILM, MIGRANT NARRATIVES AND OTHER MEDIA
}

The articles here presented are representative of the debates about the various transformational aspects of film studies, fostering the discussion about the transformations and interactions between national and international narrative forms, the interrelations between film and literature, and film with other media. The critical perspectives here presented range from an emphasis on cultural materialism, dialogism, reception theory, deconstructionism, narrative studies to film aesthetics or film genre, and can be grouped in three major interrelated areas of film studies: adaptation studies, representation and aesthetics, and film and other media. All of them enable a critical perspective as regards the fluidity of the boundaries separating film from other media, such as literature, television, DVDs, and video games, as newer narrative forms that are incorporated by film, and the transformations in terms of aesthetics and forms of representation in contemporary film and media (the transgeneric nature of film, the interrelations between national and international cinemas, and the demands for a broader perception of the overwhelming mediations of the image in our contemporary society). Moreover, the articles are inserted within recent critical debates on adaptation, digital media and national and transnational cinema (Naremore, Sobchack, Druckery and Williams).

\begin{tabular}{|l|l|l|l|l|}
\hline Ilha do Desterro & Florianópolis & no 51 & p.009-017 & jul./dez. 2006 \\
\hline
\end{tabular}


All articles combine important theoretical concerns with the analysis of specific films. Robert Stam's "Teoria e Prática da Adaptação: da Fidelidade à Intertextualidade" ("Theory and the practice of adaptation: from fidelity to intertextuality") offers a rich perspective on the issue of adaptation in its relationship with critical theory. He analyses the changing critical views on adaptation, which go from the priority given to the canonic literary text, as an origin, to a more fluid, intertextual and dialogical approach to film adaptation. Drawing from Bakhtin's concept of dialogism and Genette's definition of intertextuality, Stam defines new possibilities of reading film adaptation as a provocative dismantling of hierarchies in order to see it as a new form of critical reading of the literary text as well, "not necessarily subordinated to it", but as a form of intertext or transtextuality. Stam's critical perspective is further enriched with his various analyses of specific film adaptations.

Although working with different media like video games and digitalized film, Richard Grusin, in the essay "DVDs, Video Games, and the Cinema of Interactions" also reveals the demands for an intertextual approach in order to understand the existing relations among classic narrative cinema and other media. He elaborates on the lack of boundaries separating film and other media such as DVDs and video games, in what he defines as a cinema of "interactions" — an analogy to the early cinema of "attractions" and its reliance on the vaudeville, magic lantern shows, panoramas, traveling shows-, and the "remediation of plays, novels and other familiar stories like 'The Passion"' (74). According to Grusin, cinema has always been mediated by other narrative forms, for cinema is the remediation of an already mediated world. In his analysis of films like The Matrix Reloaded, Run, Lola Run or the hyper mediated Tulse Luper project by Greenaway, the production, distribution and reading of these films promote new challenges and possibilities of incorporating a new narrative logic, less based on the centrality of subjectivity and the realism associated with classic film. 
In "Da Violência Justiceira à Violência Ressentida" ("From lawful violence to resentful violence"), Ismail Xavier discusses the changing forms of representations of the bandit in contemporary Brazilian films, as compared to Cinema Novo (more specifically his analysis of Perfumed Ball (1996) in comparison to films like Glauber Rocha's Deus e o Diabo na Terra do Sol (1964), or Os Fuzis (1964). Xavier points out the differences in the representation of violence in contemporary films as it incorporates and projects new forms of violence more associated with an urban and capitalist environment in which self-interest, the powerlessness of the State, and the cangaceiro's distancing from his collectivity devoid violence from a sense of justice and justified revenge. Xavier's article contextualizes the changing forms of representation of violence in Brazilian cinema-changes that, despite their specificities, map out an ironic perception of the lack of a collective national project, but which are still inserted in a market economy that is quite tuned in to the demands of national and international audiences.

The importance of representation for one's understanding of the interrelations between a national and an international film industry is also discussed in José Gatti's essay "Carmen Miranda's White Dress: Ethnicity, Syncretism and Subaltern Sexualities in Springtime in the Rockies". Gatti discusses the sophisticated role played by Carmen Miranda as an icon in contemporary cultural industry, whose influence went far beyond her alleged performance as a "Brazilian cultural ambassador in the United States" (92). Gatti argues that in spite of all critiques of Carmen Miranda's alleged manipulation by the Hollywood industry, she was the "auteur of her own persona", as a sort of "multiauthor" capable of adapting her own needs and personal/political projects to the agenda imposed by the film industry. This sense of malleability, flexibility, and adaptation allowed Carmen Miranda to negotiate her position within the film industry. Furthermore, such intricacies in the relationship established between the star and the industry create a space for a more sophisticated analysis of the interrelations between national culture and the international industry. 
In "Techno-Euphoria and the World-Improving Dream", Robert Burgoyne analyses the developments of the epic film from the theoretical perspective of its double-voicing of national and transnational historical aspirations. Instead of reinforcing the analogy between Ancient Rome and the ideological imperialistic forces associated with contemporary policies by US governments, Burgoyne's essay retrieves the crisis inscribed in contemporary US history, more specifically after the $9 / 11$ events, and the ways in which the film portrays the dualism between "bare life" and "sovereignty" in the film Gladiator, in a reference to Antonio Agambem's Homo Sacre: Sovereign Power and Bare Life (118). Burgoyne reveals that the epic film plays a double role or conveys a double voicing of antithetical forces within a global context since consciousness and desire for change, which is construed by the film narrative, counter-argue "hegemonic" needs (125). In this case, there is an attempt to transcend the national hegemonic imperialistic roles assigned to the film (and by extension, to Hollywood epic films) so as to contextualize it within a transnational scenario in which minorities are inserted within a new ethics, as a "force of resistance" against the state.

The borders separating the center and the marginal in film production are well defined in Bernadette Lyra's essay "Horror, Humor eSexo no Cinema de Bordas" ("Horror, humor, and sex in the marginal cinema"). According to the author, o cinema de bordas ("marginal cinema") is constituted by recycled fragments from various genres and subgenres without a determinant mode. Such a generic recycling favors repetition and continuity of that which is already known in order to sustain forms of action and feelings most common in popular literature. Her analysis focuses on the production of horror, humor, and sex as forms that are commonly excluded from the centrality of the canonic. Drawing a panorama of various genres such as the horror in the thirties and forties in the productions by Universal Studios, RKO up to the Godzilla and their recycling on TV (as well as their use of the detective and horror canonic literature by Poe, Lovecraft, Wallace and 
others), Lyra emphasizes the blending of the popular cultural production and the erudite in cinema de bordas. Besides analysing the uses of humor and sex in filmic production, within a Brazilian context she also analyses a genre created by Ivan Cardoso, terrir, and his production of parodies such as Nosferatu in Brasil. Such a genre functioned as a counter cinema to the so called realism associated with classic cinema and to the seriousness and nationalistic project associated with Cinema Novo (140).

In "Imagens negociadas: o Experimental no Cinema" ("Negotiated images: the experimental in cinema"), Andrea França questions the alleged realism of documentary production in her analysis of two recent digital documentary productions: A pessoa é para o que nascee Passaporte húngaro. França points out the ways in which recent digital documentary problematizes the very concept of representation to evince "multiple ways of visibility to the image" itself (158). Along the lines of a discussion of a new aesthetics of the image, in "Beleza, Beleza e Nada Mais" ("Beauty, beauty and nothing else"), Denilson Lopes argues for the possibility of retrieving an aesthetic experience within our mediatic society through the category of the sublime. As Lopes points out, his interest lies on "a hybrid aesthetics, intertextual, transsemiotic and mutimediatic...more distanced from definitions of fields of knowledge and artistic languages" (170). He proposes a discussion of the image as a form that is everywhere and cannot be compartmentalized by specific areas or fields of knowledge-an aesthetics that would break the barriers separating the disciplines. The article "Genital Impacts", by Luiz Felipe Soares, also addresses the shocking effect of the image, but with an emphasis on images of genitalia in recent films. Soares raises the point that the centrality of seduction in different narratives implies their hiding from the screen the very image of genitalia since its appearance suppresses the game of representation, as the game of seduction. According to Soares, "on the pornographic image there is nothing to be seen beyond image": once genitalia appears, the flow of narrative/seduction games is often 
suspended for the sake of the image itself, not as a window to an external reality, but as an unreadable end or enigma in itself. As Soares points out, "genitalia, as image, turn into enigma, in the very passage from nature to culture" (192).

Still addressing issues of representation and the expanding borders of the cultural impact of cinema, in "Learning to live with the other in America" Mauro Pommer explores the association between filmic representation and its influence and relationship with economic modes of production in the US. His article departs from Michael Moore's Bowling for Columbine and Morgan Spurlock's Super Size Me to establish an analogy between violence and "overgrown bodies", and American models of economic production. Pommer compares the accommodating ways of representations of obesity in film comedies with the denouncing tone of Moore and Spurlock's documentaries. In the latter, the denouncement relies on the "standardization" of the "over-sized body" and food due to economic modes of production that hardly respect individual needs. For Pommer, such standardization can also be associated with the alarming rate of massive killings as a form of elimination of that which is not inserted within the realm of normality or the standard norms.

The following group of articles, by Diniz, Azerêdo, Creus and Teixeira, address the breaking of boundaries separating film from literature from a perspective that problematizes the very concept of adaptation by emphasizing the changes and departures in the filmic texts when compared to the literary texts. In Thaïs Flores Diniz's analysis of Spike Jonze's Adaptation., the concept of adaptation is introduced in the light of recent theories proposed by Naremore and others to claim that the adaptation created within the story of Adaptation. departs from traditional, hierarchical concepts of the practice of adaptation. In a similar way, Genilda Azerêdo's article "From Emma to Clueless: Ironic Representations of Jane Austen" proposes that an adaptation that would do justice to the centrality of irony in Emma can be achieved in filmic texts that are capable of distancing themselves from questions of 
"faithfulness" in order to reinscribe irony to a contemporary audience capable of reading the distance separating Austen's and our world. For Azerêdo, Clueless presents a "double construction...as a film that incorporates and criticizes elements from Austen's world" (256). This same notion of the reinscription of the adapted text to a contemporary audience is developed in Antonio João Teixeira's "The construction of national identity in Shakespeare's King Lear and its filmic adaptation by Peter Brook". Teixeira analyses the choices and selections made by Brook in terms of his use of a minimalist mise-en-scène and his reliance on an aesthetics of the art film of the sixties and seventies. As Teixeira explains, "The bleak, nihilistic view of the film is related to theatrical experiments of the sixties-the Theater of the Absurd, the Theater of Cruelty, the Poor Theatre-and to the philosophical existentialist ideas of postwar Europe" (296).

The view on adaptation as an intertextual practice, inclusive of the uses of images and narratives produced within our contemporary cultural production, is further discussed in Tomás Creus's "When Harry Met Zuckerman: Self-Reflexivity and Metafiction in Philip Roth". Creus foregrounds the interrelations between Woody Allen's and Philip Roth's work in their similar treatment of various subjects and personal experiences, as a form of dialogue between the two artists.

If intertextuality is a common practice among writers and directors along the centuries, the creation and general use of digital media have accelerated it with the inclusion of the viewer/audience as an active part in this process. In "Indexicality and Spectatorship in Digital Media: Waking Life as a Hybrid Artifact", Erik Marshall analyses Waking Life as a film that exemplifies the "working across most of the registers of digital media" and which problematizes the realism associated with film. Marshall proposes the definition of a subjective realism that would take "into account diverse viewing environments as changing aesthetics would unite discourse of spectatorship and realism in useful ways" (316). The relationship between media and forms of production is also problematized in Anna 
McCarthy's "Television and Public Service in the United States: Writing the History of a Problem". McCarthy analyses the ways in which television has been used as a vehicle for public broadcasting since its foundation, in 1927, up to the establishment of a Public Broadcasting Service in the US. The interrelations established between technology and public policies make clear that there is no neutral form of technology and it needs to be seen within the context of different political and ideological agendas.

The last section of this issue presents reviews of Marinyse Prates de Oliveira's book on the relations among cinema, literature and nationality, entitled, Olhares Roubados: cinema, literatura e nacionalidade (2004), reviewed by Fernando Vugman; Linda Hutcheon's work on adaptation, A Theory of Adaptation (2006), reviewed by Caroline Roberto; and Carl Platinga and Greg M. Smith (eds.) work on the spectatorship and film, Passionate Views: Film, Cognition and Emotion (1999), reviewed by Maria Cecília de Miranda Nogueira Coelho. Gabriela Borges reviews the project Becket on Film (1999), produced by Gate Theatre Dublin.

The articles selected for this special issue highlight the interrelationships among film and various areas of knowledge and technologies such as literature, television and digital media. The articulation of these areas calls for new perspectives on film as a transtextual production which combines different narrative forms, representations of national and transnational cinemas, and more interactive associations between audience and the film text. To read film beyond boundaries is an attempt to present film within a broader context of relations with the other arts, technologies, disciplines, and audiences.

Anelise Reich Corseuil Universidade Federal de Santa Catarina 


\section{References}

Druckery T. (ed). Electronic Culture: Technology and Visual Representation. New York: Aperture, 1996.

Naremore, James (ed.). Film Adaptation. New Brunswick: Rutgers University Press, 2000.

Sobchack, Vivian (ed.). MetaMorphing: Visual Transformation and the Culture of Quick-Change. Minneapolis: University of Minnesota Press, 2000.

Williams, Alan (ed.). Film and Nationalism. New Brunswick: Rutgers University Press, 2002. 